\title{
PEMBENTUKAN INSTITUSI PENGAJIAN TINGGI BERTERASKAN WAKAF DI MALAYSIA: CADANGAN MODEL PELAKSANAANNYA
}

\section{The Establishment of a Waqf-Based Higher Educational Institution in Malaysia: Proposed Model for Implementation}

\author{
Siti Mashitoh Mahamood ${ }^{1}$ \\ Asmak Ab Rahman ${ }^{2}$ \\ Azizi Che Seman ${ }^{3}$
}

\begin{abstract}
The article discusses the establishment of higher educational institution using waqf instrument. It suggests a model for the establishment to be applied in waqf-based higher education institutions in Malaysia based on the existing legislations and the contemporary needs. The model has used the research data
\end{abstract}

Associate Professor, Department of Shariah and Law, Academy of Islamic Studies, University of Malaya, 50603 Kuala Lumpur, mas68@um.edu.my. The writer is also the Director of UM AWQAF (University of Malaya AWQAF).

2 Head, Department of Shariah and Economics, Academy of Islamic Studies, University of Malaya, 50603 Kuala Lumpur, asmak@um.edu.my. The writer is also a member of the Administrative Committee, UM AWQAF.

3 Senior Lecturer, Department of Shariah and Economics, Academy of Islamic Studies, University of Malaya, 50603 Kuala Lumpur, azizi@um.edu.my. The writer is also a member of the Administrative Committee, UM AWQAF. 
collected from a selected international Waqf and Endowment Universities which had been carried out from 2012-2017.

Keywords: higher educational institution, waqf, endowment, Malaysia, laws

\section{PENDAHULUAN}

Wakaf dan pendidikan merupakan dua keperluan yang saling berkait rapat dan tidak dapat dipisahkan sedari dulu. Sejarah mencatatkan bahawa institusi pendidikan pada masa silam telah dibiayai daripada sumber wakaf di mana pada kebiasaannya tujuan wakaf adalah ditentukan oleh pewakaf sendiri. ${ }^{4}$

Di Jerusalem misalnya terdapat 70 sekolah wakaf yang ditubuhkan pada awal abad ke-5 dan 12 di mana pendidikan secara percuma telah disediakan kepada pelajar. Ini termasuk geran dan peruntukan kepada sekolah yang turut dinikmati oleh mereka. Semasa pemerintahan Islam di Kepulauan Sicily, terdapat 300 sekolah rendah yang dibuat berteraskan wakaf. ${ }^{5}$

Wakaf Al-Azhar yang diasaskan oleh Dinasti Fatimiyyah pada 970M kekal memberi manfaat kepada para pelajar sehingga kini di mana pendidikan secara percuma telah diberikan kepada mereka, tertakluk kepada syarat dan pilihan pewakaf sendiri. ${ }^{6}$ Wakaf ini juga telah dapat membantu negara Mesir ketika negara ini berhadapan dengan kegawatan ekonomi pada satu ketika dulu. ${ }^{7}$

Universiti of Al-Qurawiyin di Fez, Morocco, Universiti Al-Muntasiriyyah di Iraq, dan Universiti Cordova di Spain adalah antara institusi pengajian terkenal yang dibangunkan daripada sumber wakaf. Selain itu, Universiti King Abdul Aziz UAE, termasuklah Vakif Üniversitesi di Turki telah melaksanakan wakaf dengan jayanya masakini. Di Istanbul sahaja misalnya, bilangan Vakif Üniversitesinya telah melebihi 72 dan bilangan ini dijangka bertambah dari semasa ke semasa. ${ }^{8}$

4 Siti Mashitoh Mahamood, Waqf in Malaysia: Legal and Administrative Perspectives (Kuala Lumpur: UM Press, 2006), 2-4.

5 Siti Mashitoh Mahamood, Waqf in Malaysia: Legal and Administrative Perspectives, 3.

6 Ibrahim Salah Hudhud (Profesor, Rektor Universiti Al-Azhar di Universiti alAzhar, Kaherah), dalam temu bual beliau bersama penulis, pada 22 Februari 2016.

7 Siti Mashitoh Mahamood \& Asmak Ab Rahman, 'Financing Universities Through Waqf, Pious Endowment: Is It Possible?', Humanomics, 31/4 (2015), 432.

8 Siti Mashitoh Mahamood \& Asmak Ab Rahman, 'Financing Universities Through Waqf, Pious Endowment: Is It Possible?’, 432. 
Pada masa kini, kehebatan wakaf kekal dimartabatkan dalam bidang pendidikan khususnya pendidikan tinggi yang diaplikasikan bukan sahaja di negara-negara Islam, malah negara Barat juga tidak terkecuali dalam pelaksanaan agung ini.

Kehebatan negara Barat khususnya UK dan US dalam perolehan dana berbentuk endowmen seringkali menjadi ikutan kepada amalan global. Tanpa disedari, amalan tersebut pada hakikatnya adalah berteraskan konsep dan prinsip wakaf sebagaimana yang telah dinyatakan oleh Professor $\mathrm{Dr}$ Murat Çizakça, ${ }^{9}$ seorang pakar kewangan Islam yang berasal daripada Turki bahawa Universiti ${ }^{10}$ Oxford dan Cambridge telah mengambil idea daripada wakaf Islam bagi membiayai IPT mereka pada awalnya. Menurutnya, konsep amanah ataupun "trust" yang dilaksanakan di Merton College ${ }^{11}$ pada tahun 1262 oleh Walter de Merton, iaitu pengasas Merton College adalah merupakan suatu yang menyamai wakaf Islam klasik. Hal ini telah menyebabkan Monica Gaudiosi yang mengkaji tentang asal-usul konsep amanah Inggeris selanjutnya membuat kesimpulan bahawa konsep amanah Inggeris ini sebenarnya adalah berteraskan wakaf Islam itu sendiri. Professor Dr Murat Çizakça, ${ }^{12}$ amalan Oxford itu kemudiannya diikuti oleh Peter House College ${ }^{13}$ di Universiti Cambridge. ${ }^{14}$ Inilah yang menunjukkan bahawa Oxford dan Cambridge telah mengambil konsep wakaf dalam Islam.

Fakta di atas menunjukkan bahawa konsep wakaf bukanlah sesuatu yang asing kepada Barat. Malah dapat dilihat bahawa konsep dan prinsip wakaf dan amanah Inggeris mempunyai persamaan meskipun terdapat beberapa perbezaan signifikan di antara kedua-duanya. Ini dapat dilihat misalnya perkara berkaitan keperluan elemen kekal, pemilikan mawquf, kuasa mutawalli dan lain-lain

9 Murat Çizakça (Professor, Joint Director of Research, INCEIF Malaysia), dalam temu bual beliau bersama penulis pada 10 Oktober 2012.

10 Iaitu merujuk kepada kolej-kolej di bawahnya yang dikenali sebagai Oxbridge.

11 Merton College adalah salah satu kolej di bawah Oxford University di UK.

12 Murat Çizakça (Professor, Joint Director of Research, INCEIF Malaysia), dalam temu bual beliau bersama penulis pada 10 Oktober 2012.

13 Peter House College adalah salah satu kolej di bawah Cambridge University di UK.

14 Çizakça, Murat, A History of Philantropic Foundations: The Islamic World From The Seventh Century to The Present (Istanbul: Bogazici University Press, 2000), 12. 
lagi. Atas dasar inilah juga kebanyakan statut berkaitan wakaf di Malaysia telah memperuntukkan bahawa tafsiran wakaf tidak termasuk amanah. ${ }^{15}$

Kini pelaksanaan endowmen telah menjadi kebanggaan Universiti di Barat khususnya UK dan US sehinggakan IPT ini saling berlumba-lumba dalam perolehan endowmen di IPT mereka. ${ }^{16}$

IPT Malaysia turut melaksanakan endowmen selain wakaf. Perkembangan terkini menyaksikan Universiti Awam (UA) kini telah mula mengorak langkah aktif ke arah memperkenalkan wakaf di institusi masing-masing. Ianya dilaksanakan secara lebih rancak semenjak tahun 2016 apabila Menteri Pengajian Tinggi, YB Dato' Seri Idris bin Jusoh meminta setiap UA menubuhkan tabung wakaf. ${ }^{17}$

Walau bagaimanapun, tidak dapat dinafikan bahawa wakaf pendidikan telah lama wujud di negara ini menerusi pembinaan masjid, surau, madrasah dan pondok yang telah dilakukan oleh masyarakat tempatan, mahupun masyarakat luar yang berhijrah ke negara ini. Ini termasuk juga sumbangan daripada pihak pemerintah dan pembesar negeri dalam membangunkan institusi yang berteraskan pendidikan Islam di rantau ini. ${ }^{18}$ Sumbangan yang dibuat melalui

15 Iaitu amanah yang ditafsirkan berdasarkan undang-undang amanah Inggeris. Lihat Siti Mashitoh Mahamood \& Asmak Ab Rahman, 'Financing Universities Through Waqf, Pious Endowment: Is It Possible?', 437. Sebagai contoh peruntukan statut berkaitan wakaf ini, lihat Subseksyen S.2(1) Enakmen Wakaf (Negeri Selangor) 2015 (Enakmen 15): “wakaf” ertinya-

(a) menyerahkan hak milik apa-apa harta yang boleh dinikmati manfaat atau kepentingannya;

(b) menyerahkan manfaat atau kepentingan yang boleh dinikmati daripada apaapa harta; atau

(c) menyumbangkan kepakaran dan perkhidmatan yang boleh dinikmati manfaat atau kepentingannya,

sama ada sebagai wakaf am atau wakaf khas, menurut Hukum Syarak, tetapi tidak termasuk amanah yang ditakrifkan di bawah Akta Pemegang Amanah 1949 [Akta 208];”.

16 Lihat The Sutton Trust (2003), "Higher education white paper", Discussion Paper On University Endowments - A UK/US Comparison, London, May 2003.

17 Berita Harian (2016), “Tabung Wakaf Tampung Kos Universiti”, 24 Ogos 2016.

18 Siti Mashitoh Mahamood, 'Peranan Harta Al-Sadaqah dalam Sistem Pendidikan: Pengalaman Sejarah Awal Islam Serta Penghayatannya dalam Perkembangan Institusi Pendidikan Kini,' (Kertas kerja, Seminar Kebangsaan Peranan Harta AlSadaqah dalam Memartabatkan Pembangunan dan Pendidikan Ummah, Dewan Bestari, Intekma Resort, UiTM, Shah Alam, 14 Januari 2004), 15. Lihat juga Abdullah Alwi Haji Hassan, The Administration of Islamic Law in Kelantan (Kuala Lumpur: DBP, 1996), 222. 
wakaf, sama ada daripada bentuk wakaf am, wakaf khas ataupun wakaf irsad amat dominan dalam pembangunan ini.

Setakat ini, terdapat 12 UA yang telah mula melaksanakan kutipan dan pembangunan wakaf melibatkan UPM, USIM,UKM, USM, UMT, UTHM, UTM, UiTM, UniSZA, UMP, UNIMAP dan UTEM. Kutipan terkini telah mencecah sehingga RM25.7 juta. Terdapat lapan lagi UA yang belum dapat melaksanakannya kerana proses pelaksanaannya masih berjalan melibatkan UM, UIAM, UPNM, UUM, UNIMAS, UMS, UMK dan UPSI. ${ }^{19}$

Pelaksanaan wakaf di IPT dan UA adalah sangat penting memandangkan instrumen ini dapat menjadi alternatif terbaik bagi meringankan beban yang ditanggung dalam kos pembangunan dan penyediaan infrastruktur bagi manfaat para pelajar dan warga IPT. Meskipun peruntukan bajet kepada pendidikan tinggi bagi tahun 2018 telah meningkat sebanyak 13.15 peratus, iaitu daripada RM12.28 bilion kepada RM13.89 bilion $^{20}$ namun persediaan yang strategik adalah diperlukan bagi menambah dana dan harta melalui wakaf untuk menghasilkan pendapatan yang mampan akan mempastikan kelestarian IPT.

Dengan terlaksananya wakaf di UA, maka penulis berpandangan perlu ada satu model pelaksanaan yang spesifik untuk dijadikan panduan kepada semua IPT wakaf negara. Artikel ini mengandungi cadangan pembentukan model pelaksanaan wakaf di IPT yang tidak hanya melibatkan kerangka organisasi semata-mata, malah komponen-komponen utama penubuhannya adalah dipersembahkan secara komprehensif. Kandungannya adalah didasarkan kepada pengalaman Data yang dibentangkan adalah diambil daripada hasilhasil penyelidikan empirikal berkaitan Universiti Wakaf dan Endowmen yang telah dilaksanakan oleh penulis semenjak tahun 2012 sehinggalah tahun 2017. Ianya telah dilaksanakan di Malaysia, Turki, Mesir, UK, US, Kuwait, Maghribi dan Indonesia. ${ }^{21}$

19 Noranyza Mohamad Yusoff (Ketua Program (PMO), Pejabat Pengurusan Program (PMO)), data diperolehi daripada beliau menerusi aplikasi WhatsApp pada 6 November 2017.

20 Berita Harian Online (2017), "Bajet 'Soaring Upwards”, 7 November 2017.

21 Penyelidikan-penyelidikan tersebut adalah "Towards the establishment of a Malaysian waqf university: conceptualization \& Model for development" (RG 284-11 HNE), "Establishment and Development of a Contemporary Malaysian Waqf University Model: Experience Learnt From Egypt, UK \& US" (RP012D13HNE) dan "Financing, Development \& Investment of Higher Educational Institutions Using Waqf Instrument: A Study in Malaysia \& Some Selected Countries"(LRGS/2013/UKM-UM/SI/02). 


\title{
KEDUDUKAN WAKAF DALAM MAJLIS AGAMA ISLAM NEGERI
}

Berdasarkan Butiran 1, Senarai Negeri, Jadual Kesembilan, Perlembagaan Persekutuan Malaysia, perkara wakaf terletak di bawah bidang kuasa negeri. Oleh itu, sebarang bentuk pelaksanaan perlu mengikuti segala undang-undang yang diluluskan.

Mengikut undang-undang negeri, Majlis Agama Islam Negeri (MAIN) adalah merupakan pemegang amanah tunggal bagi semua wakaf yang diwujudkan di negeri-negeri. Sebagai contoh, Seksyen 61 Akta Pentadbiran Undang-Undang Islam (Wilayah-Wilayah Persekutuan) 1993 (Akta 505) sebagaimana berikut:

\begin{abstract}
"Walau apa pun apa-apa peruntukan yang bertentangan yang terkandung dalam mana-mana suratcara atau perisytiharan yang mewujudkan, mengawal, atau menyentuh perkara itu, Majlis hendaklah menjadi pemegang amanah yang tunggal bagi semua wakaf, sama ada wakaf am atau wakaf khas, semua nazr 'am, dan semua amanah daripada segala perihal yang mewujudkan apa-apa amanah khairat bagi menyokong dan memajukan agama Islam atau bagi faedah orang-orang Islam mengikut Hukum Syarak, setakat mana-mana harta yang tersentuh olehnya dan terletak di dalam Wilayah-Wilayah Persekutuan dan, jika pemberi harta itu atau orang lain yang mewujudkan amanah, wakaf atau nazr 'am itu telah berdomisil di Wilayah-Wilayah Persekutuan, setakat semua harta yang tersentuh olehnya di mana-mana jua harta itu terletak".
\end{abstract}

Justeru sebarang pelaksanaan dan pengurusan wakaf hendaklah terlebih dahulu mendapatkan kebenaran daripada MAIN. Ini termasuklah pelaksanaan dan pengurusan wakaf di IPT di mana pihak IPT perlu memohon secara bertulis kepada MAIN untuk tujuan tersebut.

\section{MODUS OPERANDI PELAKSANAAN WAKAF IPT}

Di peringkat awal penubuhan, pelaksanaan wakaf IPT hendaklah memenuhi perkara-perkara penting berikut:

a) Mendapatkan kebenaran MAIN selaku pemegang amanah tunggal (sole trustee) harta wakaf berdasarkan undang-undang negara sebagaimana yang dijelaskan di atas tadi;

b) Menubuhkan pusat/bahagian/unit wakaf; 
c) Mewujudkan Pengurusan Wakaf IPT;

d) Mewujudkan Jawatankuasa Bersama IPT-MAIN;

e) Mewujudkan platform penerimaan wakaf menerusi pelbagai saluran (seperti menerusi elektronik, kaunter dan sebagainya) dari pelbagai pihak;

f) Pewakaf boleh terdiri daripada individu mahupun syarikat termasuk daripada luar negara;

g) Penerima wakaf meliputi IPT dan seluruh warga IPT (termasuk pesakit Pusat Perubatan IPT) tertakluk kepada syarat wakaf yang ditetapkan (jika ada).

h) Melaksanakan wakaf dengan kebenaran MAIN mengikut mana yang berkenaan; ${ }^{22}$ dan.

i) Mempastikan pelaksanaan wakaf termasuklah berkaitan pembangunan dan pelaburan mawquf bertepatan dengan polisi, undang-undang dan peraturan serta fatwa yang diputuskan oleh MAIN mengikut mana yang berkenaan.

\section{MODEL PELAKSANAAN WAKAF DI IPT}

IPT perlu jelas apakah konsep dan prinsip pelaksanaan wakaf yang akan digunapakai. Ianya perlu dibuat selaras dengan keperluan IPT tanpa menafikan keselarasannya dengan undang-undang serta fatwa semasa negeri berkenaan. Ini memandangkan perkara wakaf adalah perkara negeri di mana sebarang bentuk pelaksanaan hendaklah mengikuti ketetapan-ketetapan yang telah dibuat oleh pihak berautoriti negeri.

Berikut dinyatakan beberapa komponen penting yang perlu diambil perhatian oleh IPT yang hendak menubuhkan dan melaksanakan wakaf di institusi masing-masing:

\section{Tafsiran Wakaf}

Wakaf yang dilaksanakan di IPT adalah merupakan: "Suatu wakaf bagi tujuan pendidikan yang melibatkan pemberian suatu harta yang boleh dinikmati

22 Ini bermaksud sebarang aktiviti kutipan dan pembangunan wakaf yang dijalankan di suatu negeri hendaklah terlebih dahulu mendapatkan kebenaran MAIN di negeri tersebut. Sebagai contoh, jika MAIWP membenarkan UM AWQAF melaksanakan wakaf, maka kutipan hanya boleh dibuat di Wilayah-wilayah Persekutuan sahaja. Jika kutipan hendak dibuat di Negeri Selangor, maka kebenaran MAIS/PWS hendaklah didapatkan terlebih dahulu. 
manfaat atau faedahnya daripada seseorang pewakaf sama ada terdiri daripada kalangan individu, institusi ataupun pihak Kerajaan kepada IPT untuk apa-apa tujuan pendidikan bagi manfaat IPT dan seluruh warga IPT menurut Hukum Syarak dan undang-undang yang berkuatkuasa".

Tertakluk kepada fokus dan kehendak IPT, mungkin terdapat sesetengah IPT yang mahukan supaya wakafnya dapat dimanfaatkan oleh tujuan perubatan terutama sekali apabila IPT berkenaan mempunyai pusat perubatan tersendiri seperti Universiti Malaya dan Universiti Kebangsaan Malaysia. Jika ini relevan, maka tafsiran wakafnya dapat dibuat sebagaimana berikut:

"Suatu wakaf bagi tujuan pendidikan dan perubatan yang
melibatkan pemberian suatu harta yang boleh dinikmati manfaat
atau faedahnya daripada seseorang pewakaf sama ada terdiri
daripada kalangan individu, institusi ataupun pihak Kerajaan
kepada IPT untuk apa-apa tujuan pendidikan dan perubatan
bagi manfaat IPT dan seluruh warga IPT serta pesakit Pusat
Perubatan .......................... (masukkan nama Pusat Perubatan
IPT) menurut Hukum Syarak dan undang-undang yang
berkuatkuasa".

\section{Objektif Utama Pelaksanaan Wakaf}

Objektif yang digariskan hendaklah selari dengan kandungan tafsiran wakaf yang dibuat.

Berikut dinyatakan contoh objektifutama wakaf IPT dengan mengambilkira pelaksanaannya yang akan membabitkan Pusat Perubatan bersama, iaitu:

a) Membolehkan IPT menjana pendapatan sendiri menerusi kutipan wakaf untuk digunakan oleh IPT, para pelajar dan warga IPT serta pesakit Pusat Perubatan . (masukkan nama Pusat Perubatan IPT);

b) Membantu para pelajar dan staf IPT serta pesakit Pusat Perubatan yang memerlukan bantuan kewangan bagi mengatasi kos kehidupan dan perubatan; dan

c) Membiayai aktiviti-aktiviti akademik dan pembangunan fizikal melibatkan pengajian, penyelidikan, penerbitan, perubatan dan lain-lainnya.

\section{Struktur Organisasi Wakaf IPT}

Struktur Organisasi Wakaf IPT merupakan antara komponen terawal yang penting bagi pelaksanaan suatu wakaf yang hendak dijalankan. Ianya perlu 
dibincangkan secara profesional dan teliti supaya pelaksanaan wakaf dapat dibuat dengan efisyen dan berjaya. Perbezaan struktur mungkin akan berlaku di antara satu IPT dengan yang lainnya yang didasarkan kepada perbezaan MAIN dan negeri di mana IPT terletak, dasar, polisi serta undang-undang yang berkuatkuasa serta perkara-perkara lain yang diberi pertimbangan.

Berdasarkan perundangan yang meletakkan DYMM Sultan/Raja atau DYMM Seri Paduka Baginda Yang di-Pertuan Agong $^{23}$ sebagai ketua agama Islam negeri-negeri, maka adalah wajar Organisasi Wakaf IPT dinaungi oleh mereka.Tertakluk kepada perbincangan dan keperluan, Canselor IPT boleh diletakkan sebagai Penasihat.

Selanjutnya pengurusan utama Wakaf IPT perlu terdiri daripada dua kategori berikut iaitu:

a) Lembaga Wakaf IPT

b) Badan Pengurusan Wakaf IPT

Lembaga Wakaf IPT ini adalah berfungsi sebagai Jawatankuasa Bersama Wakaf IPT-MAIN. Bagi IPT di mana MAINnya belum mempunyai peruntukan spesifik tentang kebenaran pihak lain (selain MAIN) untuk menguruskan wakaf, ${ }^{24}$ maka pemakaian nomenklatur Jawatankuasa Bersama Wakaf IPTMAIN atau Jawatankuasa Bersama Wakaf IPT hendaklah digunakan. Ini supaya selari dengan peruntukan sedia ada bahawa MAIN boleh mewakilkan kepada mana-mana jawatankuasa yang dibentuk olehnya bagi pelaksanaan kewajipannya atau penjalanan mana-mana kuasanya ${ }^{25}$ di mana ianya adalah termasuk perkara wakaf.

23 Iaitu bagi negeri-negeri yang tidak beraja melibatkan Wilayah-wilayah Persekutuan, Melaka, Pulau Pinang, Sabah dan Sarawak.

24 Sebagai contoh di bawah Selangor, Subseksyen 4(1). Enakmen Wakaf (Negeri Selangor) 2015 (Enakmen 15) memperuntukkan:

"Majlis hendaklah menjadi pemegang amanah tunggal bagi semua wakaf yang terletak di dalam Negeri Selangor dan hendaklah mempunyai kuasa untuk:

(a) mewujudkan Perbadanan;

(b) melantik atau memberi kebenaran bertulis kepada mana- mana orang untuk menjadi pentadbir atau pengurus dan memegang apa-apa mawquf bagi pihaknya; dan

(c) mengiktiraf pelantikan mana-mana pentadbir atau pengurus dalam keadaan yang mana waqif telah pun melantik pentadbir atau pengurusnya sendiri tertakluk kepada terma dan syarat yang ditetapkan oleh Majlis.

25 Lihat misalnya subseksyen 27(1) (Pewakilan kewajipan-kewajipan dan kuasakuasa) Akta Pentadbiran Undang-Undang Islam (Wilayah-Wilayah Persekutuan) 1993 [Akta 505] yang memperuntukkan: 
Fungsi Lembaga Wakaf IPT/Jawatankuasa Bersama Wakaf IPT-MAIN adalah menentukan dasar dan polisi serta mengawal pelaksanaan wakaf yang dibuat oleh Badan Pengurusan Wakaf IPT.

Lembaga Wakaf IPT/Jawatankuasa Bersama Wakaf IPT-MAIN ini perlu dianggotai oleh Wakil daripada IPT serta Wakil daripada MAIN. Ianya akan dipengerusikan oleh Naib Canselor IPT di mana Timbalan Pengerusinya dilantik daripada Ketua Pegawai Eksekutif MAIN. Setiausaha Lembaga/ Jawatankuasa adalah Pengarah Wakaf IPT memandangkan beliau terlibat secara langsung dalam Badan Pengurusan Wakaf IPT.

Badan Pengurusan Wakaf IPT pula akan diketuai oleh Pengarah Wakaf. Tertakluk kepada keperluan, seorang Timbalan Pengarah boleh dilantik. Mereka akan dibantu oleh seorang Pegawai Pentadbiran dan juga seorang Pegawai Projek.

Fungsi Badan Pengurusan Wakaf IPT ini adalah melaksanakan dasar dan polisi yang ditetapkan oleh Lembaga Wakaf IPT/Jawatankuasa Bersama Wakaf IPT-MAIN bagi pelaksanaan wakaf di IPT.

Bagi mempastikan urusan wakaf IPT dapat dilaksanakan dengan lebih efisyen, Pegawai-pegawai berikut dengan bidang pengkhususan kerja yang spesifik berkaitan wakaf wajar dilantik:

a) Pegawai Kewangan;

b) Pegawai Pendaftaran Wakaf;

c) Pegawai Kutipan;

d) Pegawai Agihan;

e) Pegawai Pembangunan dan Pelaburan;

f) Pegawai Pemasaran;

g) Pegawai Urusan Wakaf Pusat Perubatan IPT (jika berkenaan)

Selanjutnya, wajar ditubuhkan Badan Pengawasan Wakaf yang terdiri daripada Jawatankuasa Syariah dan Jawatankuasa Pelaburan yang akan memberi nasihat bagi perkara-perkara berkaitan Hukum Syarak dan pelaburan yang dilaksanakan oleh Badan Pengurusan Wakaf IPT.

\footnotetext{
"Majlis boleh, melalui ketetapan, dan tertakluk kepada syarat-syarat dan sekatan-sekatan sebagaimana yang difikirkan patut oleh Majlis, mewakilkan kepada Pengerusi atau Setiausaha atau kepada mana-mana jawatankuasa Majlis pelaksanaan mana-mana kewajipannya atau penjalanan mana-mana kuasanya."
} 
Sebagai alternatifnya, satu Jawatankuasa Pentadbiran boleh diwujudkan yang akan berfungsi untuk membantu dalam pelaksanaan pengurusan Wakaf IPT dan berkepakaran dalam bidang berkaitan wakaf melibatkan:

a) Fiqh Wakaf;

b) Perundangan;

c) Ekonomi Islam;

d) Kewangan dan Perbankan Islam; dan

e) Perakaunan

Pendekatan alternatif ini lebih memudahkan pengurusan wakaf IPT memandangkan segala keputusan bagi melaksanakan urusan wakaf akan dapat dibuat dengan cepat lagi tepat kerana kepakaran ahli-ahlinya dapat terus dimanfaatkan dalam menyelesaikan permasalahan yang timbul.

\section{Skop Aktiviti Utama Pelaksanaan Wakaf}

Berikut dinyatakan beberapa cadangan skop aktiviti utama yang boleh dilaksanakan oleh bahagian wakaf IPT.

a) Kutipan dan penerimaan wakaf;

b) Aktiviti melibatkan pembiayaan, pembangunan dan pelaburan patuh Syariah; dan

c) Agihan manfaat wakaf kepada benefisiari dan tujuan-tujuan lain yang dibenarkan

IPT boleh melaksanakan aktiviti-aktiviti subsidiari lain seperti melibatkan persidangan/seminar, ceramah wakaf dan lain-lainnya yang dapat menyemarakkan lagi wakaf IPT di samping menjana pendapatan tambahan IPT. Misalnya di UM AWQAF, Universiti Malaya telah di adakan Seminar Pembiayaan dan Pembangunan Wakaf IPT 2017 (Swipt'17), ${ }^{26}$ MyWaqf 1.0 ${ }^{27}$ serta aktiviti-aktiviti akademik lain seperti perundingan dan ceramah berkaitan wakaf.

26 Telah diadakan dengan jayanya pada 23-24 Mei 2017 di UM dan dirasmikan oleh Menteri Pengajian Tinggi, YB Dato' Seri Idris bin Jusoh.

27 Iaitu merupakan kursus asas untuk memahami wakaf yang telah diadakan pada 23 November 2017 di UM. 


\section{Cadangan Sumber Wakaf}

Terdapat banyak sumber wakaf yang boleh diperkenalkan dan dilaksanakan oleh IPT yang memakai pelbagai konsep wakaf dan kewangan Islam. Sebagai contoh IPT wakaf boleh memperkenalkan sumber dan produk-produk wakaf berikut:

a) Wakaf Tunai - iaitu wakaf melibatkan harta berbentuk tunai seperti wang tunai (cash waqf);

b) Saham Wakaf - iaitu wakaf melibatkan penjualan unit-unit harta tertentu yang kemudiannya diwakafkan;

c) Wakaf Saham - iaitu wakaf melibatkan saham-saham sedia ada yang dimiliki pewakaf;

d) Wakaf Irsod - iaitu wakaf melibatkan tanah daripada pihak pemerintah;

e) Wakaf Korporat - iaitu wakaf melibatkan individu atau syarikat korporat;

f) Pembiayaan daripada sukuk, crowd funding, ijarah financing dan lain-lain yang bersesuaian.

g) Lain-lain sumber yang difikirkan sesuai selaras dengan Hukum Syarak.

\section{Kegunaan Hasil Wakaf}

Hasil pendapatan yang diterima oleh IPT daripada wakaf boleh digunakan untuk pelbagai tujuan yang dibenarkan oleh Syarak dan undang-undang sepertimana:
a) Biasiswa Pelajar
b) Elaun Pelajar
c) Asrama Pelajar
d) Yuran Pengajian
e) Peralatan Pengajian
f) Penyelidikan
g) Penerbitan
h) Pusat Perubatan IPT
i) Hadiah Akademik
j) Kerusi Akademik
k) Muzium UM 
1) Gaji/elaun/honorarium Staf/Pensyarah/Pelajar;

m) Pengurusan universiti/Pusat/Fakulti/Jabatan

n) Imaret (Charitable Kitchen/Soup Kitchen)

o) Kebajikan Staf

p) Pembangunan IPT

q) Pengurusan Wakaf

r) Tujuan-tujuan lain yang sesuai.

\section{Penggunaan dan Pelaburan Mawquf}

Penggunaan dan pelaburan mawquf serta hasilnya hendaklah diaplikasikan kepada tujuan-tujuan yang menepati Syarak. Contoh penggunaannya boleh dilihat sebagaimana yang dinyatakan di atas tadi.

Berikut pula dicadangkan perincian aliran agihan bagi mawquf dan hasil mawquf yang diterima oleh IPT sebagaimana berikut:

\section{Rajah 1: Cadangan Agihan Mawquf IPT}
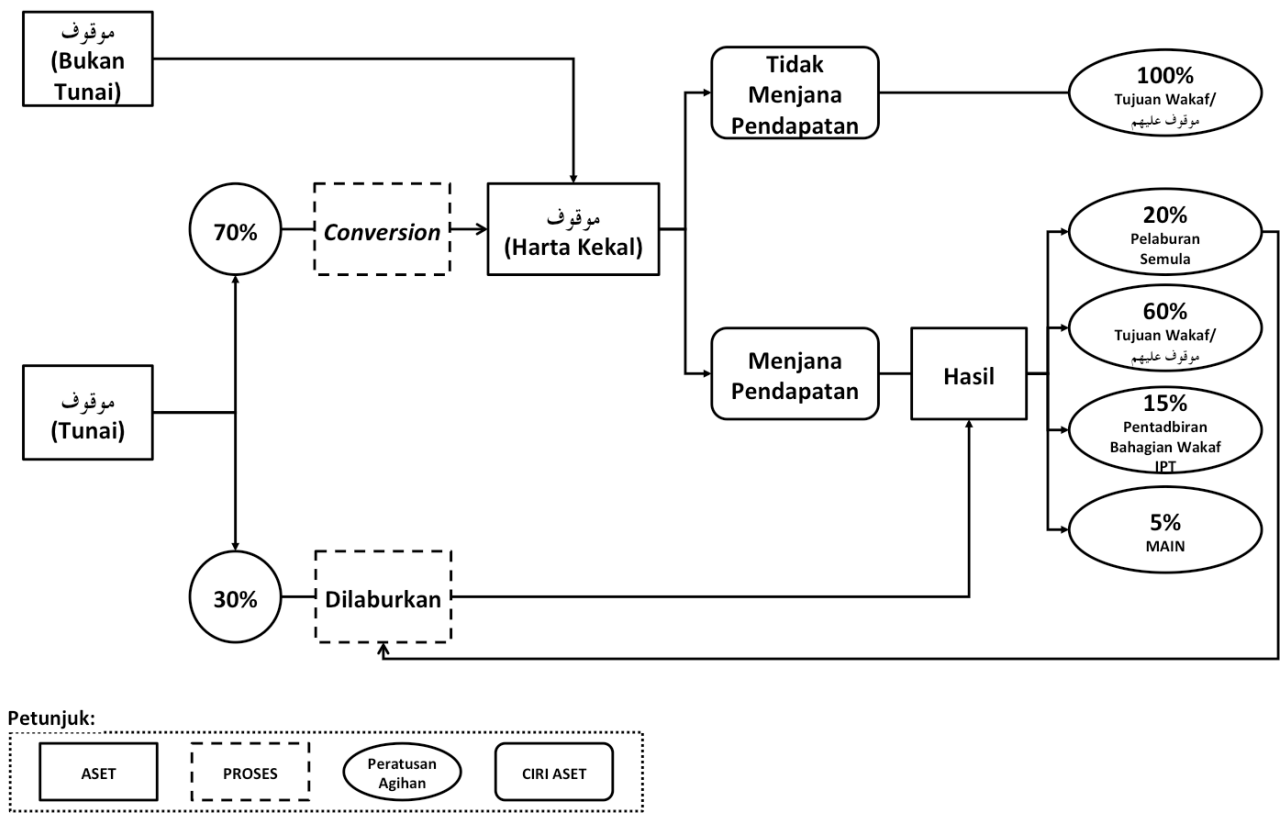

Sumber: Asmak Ab Rahman, Azizi Che Seman, Siti Mashitoh Mahamood, Wan Marhaini Wan Ahmad, Model Agihan Mawquf UM AWQAF, Hakcipta 
Universiti Malaya, no. LY2017004670, 2017. ${ }^{28}$

Berdasarkan Rajah 1 di atas, seseorang pewakaf boleh mewakafkan sama ada harta berbentuk tunai atau pun bukan tunai. Perinciannya adalah sebagaimana berikut:

\section{Mawquf Bukan Tunai}

a) Jika pewakaf mewakafkan harta bukan berbentuk tunai (melibatkan harta alih ataupun harta tak alih yang bersifat kekal), maka harta daripada kategori ini hendaklah dikenalpasti sama ada boleh menjana pendapatan atau sebaliknya.

b) Jika boleh menjana pendapatan misalnya pewakaf mewakafkan sebidang tanah, maka tanah ini dibina asrama dan asrama ini kemudiannya disewakan kepada para pelajar di mana hasil sewaan tersebut akan diagihkan berdasarkan peratusan yang telah ditentukan sebagaimana berikut:

i. $60 \%$ untuk benefisiari/tujuan wakaf

ii. $20 \%$ untuk pelaburan semula

iii. 15\% untuk perbelanjaan pentadbiran Bahagian Wakaf IPT

iv. 5\% untuk Majlis Agama Islam Negeri (pemegang amanah tunggal).

c) Bagi harta bukan berbentuk tunai di bawah kategori tidak menjana pendapatan pula, misalnya pewakaf mewakafkan buku/peralatan pengajian/mesin dialisis, maka ianya (100\%) akan terus dimanfaatkan oleh benefisiarinya yang terdiri daripada para pelajar Fakulti Perubatan IPT dan pesakit Pusat Perubatan IPT.

28 Hasil penyelidikan Projek LRGS (LR001C-2013B): "Models of Waqf Financing, Investment \& Development of Higher Educational Institutions: A Study in Malaysia \& Some Selected Countries" yang diketuai oleh Asmak Ab Rahman. Projek ini merupakan sub-projek ke-3 kepada Projek induk LRGS/2013/UKM$\mathrm{UM} / \mathrm{SI} / 02$ yang bertajuk "Financing, Development \& Investment of Higher Educational Institutions Using Waqf Instrument: A Study in Malaysia \& Some Selected Countries" yang diketuai oleh Profesor Madya Dr Siti Mashitoh Mahamood. Terdapat 2 lagi sub projek di bawah LRGS/2013/UKM-UM/SI/02 iaitu: (LR001A-2013B) "Laws, Policy \& Management of Waqf Financing, Investment \& Development of Higher Educational Institutions: A Study in Malaysia \& Some Selected Countries" yang diketuai oleh Profesor Madya Dr Siti Mashitoh Mahamood dan (LR001B-2013B) "Concepts \& Principles of Financing, Investment \& Development of Higher Educational Institutions Using Waqf Instrument" yang diketuai oleh En. Azizi Che Seman. 


\section{Mawquf Berbentuk Tunai}

a) Bagiwakafmelibatkanwang tunai, terdapatproses yangperlu disempurnakan bagi mengekalkan mawquf di bawah kategori ini berdasarkan Hukum Syarak.

b) Berdasarkan carta yang dibuat, 70\% daripada wang tunai tersebut akan ditukar kepada aset kekal di mana aset ini pula hendaklah dikenalpasti sama ada boleh menjana pendapatan atau sebaliknya. Proses yang sama seperti yang dinyatakan dalam perenggan (b) di atas adalah selanjutnya diikuti, iaitu jika aset kekal tersebut boleh menjana pendapatan misalnya dijadikan Hotel Wakaf maka hasil komersialisasinya akan diagihkan berdasarkan peratusan yang telah ditentukan berdasarkan formula peratusan yang sama, iaitu:

i. $60 \%$ untuk benefisiari/tujuan wakaf

ii. $20 \%$ untuk pelaburan semula

iii. $15 \%$ untuk perbelanjaan pentadbiran Bahagian Wakaf IPT

iv. 5\% untuk Majlis Agama Islam Negeri (pemegang amanah tunggal).

c) Jika aset kekal tersebut di bawah kategori tidak menjana pendapatan pula, misalnya dijadikan sebagai makmal Sains untuk kegunaan pelajar-pelajar Fakulti Sains atau mesin MRI untuk kegunaan para pesakit PPUM, maka sama seperti proses yang dinyatakan di dalam perenggan (c) sebelum ini, ianya $(100 \%)$ akan terus dimanfaatkan oleh benefisiarinya yang terdiri daripada pelajar-pelajar Fakulti Sains IPT dan juga para pesakit Pusat Perubatan IPT.

d) Manakala 30\% daripada wang tunai tersebut akan dilaburkan ke dalam pelaburan patuh syariah dan hasilnya akan diagihkan berdasarkan peratusan yang sama tadi iaitu melibatkan:

i. $60 \%$ untuk benefisiari/tujuan wakaf

ii. $20 \%$ untuk pelaburan semula

iii. $15 \%$ untuk perbelanjaan pentadbiran Bahagian Wakaf IPT

iv. 5\% untuk Majlis Agama Islam Negeri (pemegang amanah tunggal).

Carta Pai 1 berikut menunjukkan secara lebih jelas perincian aliran agihan hasil mawquf yang diterima oleh IPT sebagaimana yang ada dijelaskan tadi: 
Carta Pai 1: Cadangan Agihan Hasil Mawquf IPT

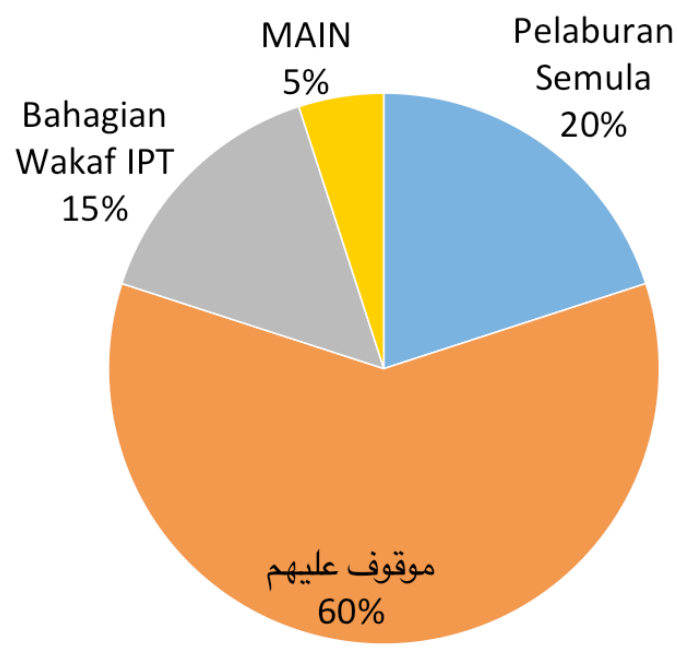

Sumber: Azizi Che Seman, Siti Mashitoh Mahamood, Asmak Ab Rahman, Wan Marhaini Wan Ahmad, Zaharah Hussin, Nor Azzah Kamri, Suhaili Sarif, Mohd Zaidi Daud, Norwati Mansor, Akhtar Zaite Abdul Aziz, Hasil penyelidikan Projek LRGS “Concepts \& Principles of Financing, Investment \& Development of Higher Educational Institutions Using Waqf Instrument (LR001B-2013B), 2017. 


\section{Contoh Model Asas Pembiayaan Wakaf Menggunakan Pendekatan Wakaf Tunai}

Rajah 2: Model Asas Pembiayaan Wakaf Menggunakan Wakaf Tunai

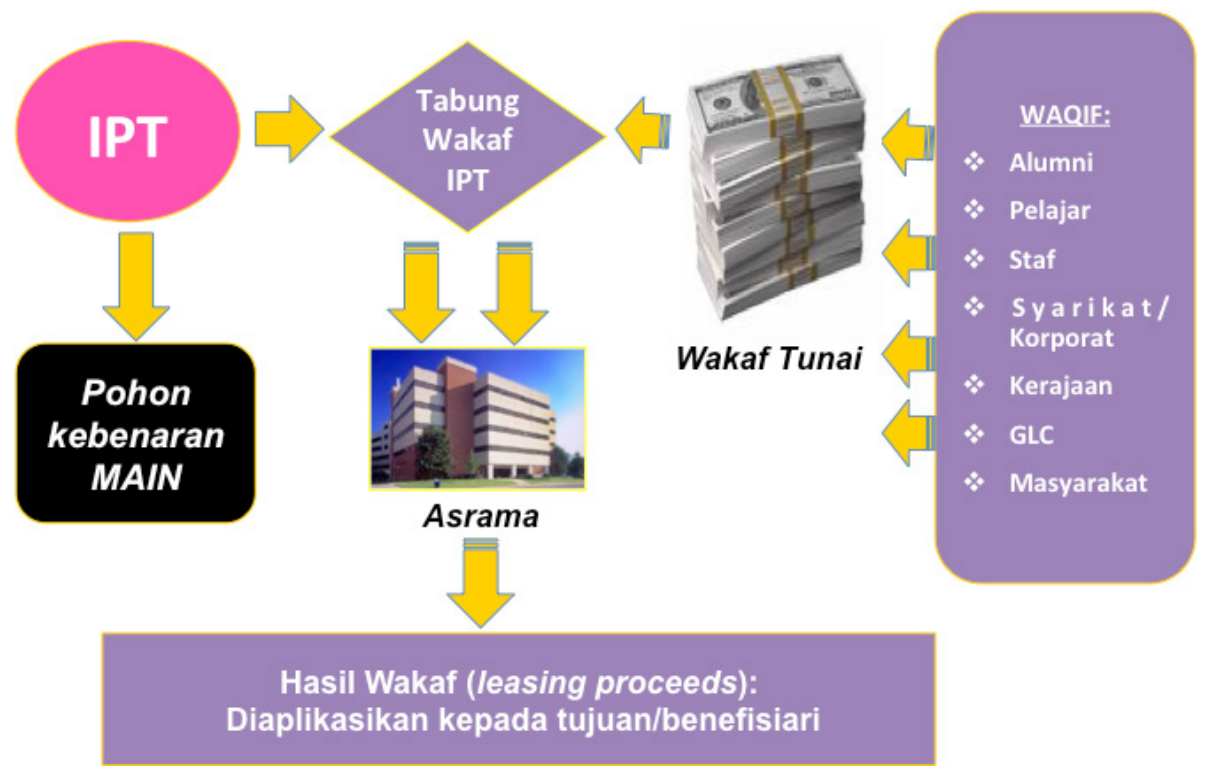

Sumber: Siti Mashitoh Mahamood, Asmak Ab Rahman, Azizi Che Seman, Mohd Zaidi Daud, Model Struktur Perundangan Bagi Asas Pembiayaan Pembangunan IPT Berteraskan Wakaf, Hakcipta Universiti Malaya, 2018. ${ }^{29}$

Rajah 2 di atas adalah antara model termudah yang dijadikan contoh bagi pemakaian wakaf melibatkan wang tunai. Proses dan perincian yang dijelaskan di perenggan berkaitan Mawquf berbentuk Tunai sebelum ini boleh dirujuk.

\section{Kaedah Pemasaran}

Bagi memastikan maklumat mengenai wakaf disebarluas khususnya kepada semua pihak yang berkepentingan tidak kira sama ada di dalam mahupun di luar IPT, pelbagai aktiviti boleh dilaksanakan termasuklah:

$29 \quad$ Hasil penyelidikan Projek LRGS (LR001A-2013B) “Laws, Policy \& Management of Waqf Financing, Investment \& Development of Higher Educational Institutions: A Study in Malaysia \& Some Selected Countries" yang diketuai oleh Profesor Madya Dr Siti Mashitoh Mahamood. 
a) Waqf Lecture/Waqf Talk

b) Jerayawara (Roadshow) kepada warga IPT (staf \& pelajar)

c) Perjumpaan dengan Alumni Universiti

d) One-to-one marketing (tumpuan kepada syarikat \& badan korporat)

e) Kempen Wakaf Untuk IPT (Waqf for IPT)

f) Kempen kepada alumni melalui telefon (Telephone Campaign)

g) Majlis Makan Malam Bersama Prospek Pewakaf

h) Karnival Wakaf

i) Hebahan melalui Media (websites, newsletter, TV Al-Hijrah, Radio IKIM untuk "Rakan Media Wakaf" dan lain-lain.)

j) Kerjasama Strategik dengan institusi perbankan Islam (cth. Bank Muamalat, Bank Islam)

k) Kaedah-kaedah lain yang difikirkan sesuai.

\section{KAWALAN DAN PEMANTAUAN MAJLIS AGAMA ISLAM NEGERI (MAIN)}

Berdasarkan kuasa MAIN sebagai pemegang amanah tunggal harta wakaf di negeri-negeri, maka IPT wakaf akan berada di bawah kawalan MAIN sepenuhnya. Setiap arahan MAIN perlu dipatuhi sewajarnya.

Bagi maksud kawalan dan pemantauan MAIN ini, Bahagian Wakaf IPT perlu memberi laporan tahunan secara bertulis kepada MAIN yang akan mengandungi perkara-perkara berkaitan kutipan, agihan, perakaunan dan juga pembangunan harta wakaf di bawah pengurusannya.

Pewujudan Lembaga Wakaf IPT dalam bentuk sebuah Jawatankuasa Bersama yang dianggotai oleh Wakil daripada IPT serta Wakil daripada MAIN akan mempastikan pelaksanaan wakaf yang dilaksanakan oleh Bahagian Wakaf IPT mematuhi segala polisi, undang-undang dan peraturan serta fatwa yang diputuskan negeri.

\section{PENGURUSAN AKAUN}

Oleh kerana wakaf mempunyai konsep dan prinsip wakaf yang spesifik dan mawquf adalah terhak kepada milikan Allah SWT, maka pendapatan suatu 
mawquf hendaklah diakaunkan secara berasingan daripada Kumpulan Wang Baitulmal MAIN ataupun Kumpulan Wang IPT.

Dalam konteks di atas, suatu Kumpulan Wang Wakaf perlu diwujudkan yang akan mengandungi akaun wakaf am dan akaun wakaf khas yang berasingan. Ini memandangkan kedua-duanya mempunyai tujuan dan benefisiari yang berbeza. Pendapatan atau hasil daripada suatu wakaf am boleh diaplikasikan kepada tujuan/benefisiari umum berdasarkan budibicara MAIN atau IPT. Malah ianya boleh juga diberikan kepada tujuan/benefisiari tertentu mengikut keperluan pada ketika itu jika pada pandangan MAIN atau IPT wajar berbuat demikian. Manakala bagi wakaf khas pula, MAIN dan IPT perlu mengikuti segala tujuan/benefisiari spesifik yang dinyatakan oleh pewakaf di mana hanya dalam keadaan-keadaan tertentu sahaja istibdal boleh dilaksanakan.

Merujuk kepada pengurusan akaun wakaf IPT pula, adalah dicadangkan pendapatan, hasil serta agihan suatu mawquf diselenggara dan diakaunkan di bawah IPT itu sendiri. Ini adalah untuk memudahkan urusan penggunaan dana dan pembangunan mawquf oleh IPT. Pihak IPT selanjutnya akan membuat laporan kewangan kepada MAIN bagi membolehkan MAIN merealisasikan peranannya sebagai pemegang amanah tunggal khususnya dalam konteks kawalan mawquf.

\section{PERLETAKHAKAN MAWQUF}

Semua harta wakaf di bawah IPT hendaklah diletakhak kepada MAIN sebagaimana yang dikehendaki mengikut peruntukan-peruntukan undangundang negeri. Sebagai contoh, subseksyen 62(1) dan subseksyen 62(2) Akta Pentadbiran Undang-Undang Islam (Wilayah-Wilayah Persekutuan) 1993 [Akta 505] memperuntukkan:

(1) Semua harta yang tertakluk kepada peruntukanperuntukan seksyen 61 dan terletak di dalam Wilayah-Wilayah Persekutuan, hendaklah, tanpa apa-apa pemindahhakan, penyerahhakan atau pemindahmilikan jua pun, dan, dalam hal harta tak alih, sebaik sahaja didaftarkan di bawah undang-undang bertulis yang relevan yang berhubungan dengan tanah, terletakhak pada Majlis, bagi maksud-maksud amanah, wakaf atau nazr 'am yang menyentuh harta itu. (2) Majlis hendaklah mengambil segala langkah perlu untuk meletakhak pada Majlis bagi maksud-maksud yang serupa mana- 
mana harta sedemikian yang terletak di luar Wilayah-Wilayah Persekutuan.

Jika IPT mempunyai mawquf yang terletak di luar daripada negeri di mana suatu IPT itu berada, maka perletakhakannya hendaklah dibuat kepada MajlisMajlis Agama Islam negeri-negeri di mana mawquf itu wujud berdasarkan undang-undang yang berkuatkuasa di negeri-negeri tersebut.

Ramai yang kurang menyedari tentang wujudnya perundangan mengenai keperluan perletakhakan ini. Peranan MAIN dalam konteks ini adalah sebagai pemegang amanah tunggal sebagaimana yang dinyatakan di dalam undang-undang. Justeru menerusi perletakhakan ini maka kuasa kawalan dan pemantauan dapat dipenuhi sebaiknya.

\section{PENUTUP}

Pewujudan model pelaksanaan wakaf di IPT merupakan suatu keperluan masakini sebagai panduan yang boleh diikuti oleh institusi-institusi pendidikan berteraskan wakaf di Malaysia. Olehkerana ianya mengambilkira pemakaian peruntukan Hukum Syarak, undang-undang serta prinsip kewangan Islam, maka model yang dibentuk ini adalah suatu yang praktikal untuk digunapakai oleh IPT di Malaysia. Pembentukannya yang didasarkan kepada hasil-hasil penyelidikan empirikal berkaitan Universiti Wakaf dan Endowmen yang telah dilaksanakan di luar negara akan dapat menjadikan model ini sebagai suatu model global yang boleh diambil manfaat daripadanya oleh Malaysia dan lain-lain negara dengan penyelarasan di mana-mana yang perlu supaya sesuai dilaksanakan.

\section{PENGHARGAAN}

Penulis mengucapkan jutaan terima kasih kepada Universiti Malaya dan juga Kementerian Pendidikan Tinggi Malaysia atas tajaan geran-geran penyelidikan (RG 284-11 HNE, "Towards the Establishment of a Malaysian Waqf University: Conceptualization \& Model For Development"), (RP012D13HNE, "Establishment and Development of a Contemporary Malaysian Waqf University Model: Experience Learnt From Egypt, UK \& US") dan (LRGS/2013/UKM-UM/SI/02, "Financing, Development \& Investment of Higher Educational Institutions Using Waqf Instrument: A Study in Malaysia \& Some Selected Countries"). Setinggi-tinggi penghargaan diucapkan kepada semua responden yang terlibat sepanjang kajian-kajian ini berjalan melibatkan IPT Wakaf dan Endowmen di Turki, Mesir, UK, US, Kuwait, Maghribi dan 
Indonesia serta IPT Wakaf di Malaysia juga Majlis-Majlis Agama Islam Negeri dan institusi-institusi berkaitan wakaf.

\section{RUJUKAN}

Abdullah Alwi Haji Hassan, The Administration of Islamic Law in Kelantan (Kuala Lumpur: DBP, 1996).

Berita Harian, “Tabung Wakaf Tampung Kos Universiti," Berita Harian, 24 Ogos 2016.

Berita Harian Online, "Bajet 'Soaring Upwards," Berita Harian Online, 7 November 2017.

Çizakça, Murat, A History of Philantropic Foundations: The Islamic World From The Seventh Century to The Present (Istanbul: Bogazici University Press, 2000).

Siti Mashitoh Mahamood \& Asmak Ab Rahman, 'Financing Universities Through Waqf, Pious Endowment: Is It Possible?', Humanomics, 31/4 (2015), 432.

Siti Mashitoh Mahamood, 'Peranan Harta Al-Sadaqah dalam Sistem Pendidikan: Pengalaman Sejarah Awal Islam Serta Penghayatannya dalam Perkembangan Institusi Pendidikan Kini,' (Kertas kerja, Seminar Kebangsaan Peranan Harta Al-Sadaqah dalam Memartabatkan Pembangunan dan Pendidikan Ummah, Dewan Bestari, Intekma Resort, UiTM, Shah Alam, 14 Januari 2004).

Siti Mashitoh Mahamood, Waqf in Malaysia: Legal and Administrative Perspectives (Kuala Lumpur: UM Press, 2006).

The Sutton Trust (2003), "Higher education white paper", Discussion Paper On University Endowments - A UK/US Comparison, London, May 2003.

\section{Statut}

Akta Pentadbiran Undang-Undang Islam (Wilayah-Wilayah Persekutuan) 1993 [Akta 505]

Enakmen Wakaf (Negeri Selangor) 2015 (Enakmen 15)

Perlembagaan Persekutuan 


\section{Temu bual}

Ibrahim Salah Hudhud (Profesor, Rektor Universiti Al-Azhar di Universiti al-Azhar, Kaherah), dalam temu bual beliau bersama penulis, pada 22 Februari 2016.

Murat Çizakça (Professor, Joint Director of Research, INCEIF Malaysia), dalam temu bual beliau bersama penulis pada 10 Oktober 2012.

Noranyza Mohamad Yusoff (Ketua Program (PMO), Pejabat Pengurusan Program (PMO)), data diperolehi daripada beliau menerusi aplikasi WhatsApp pada 6 November 2017. 